\title{
Metacaspase-binding peptide inhibits heat shock-induced death in Leishmania (L.) amazonensis
}

\author{
Mauricio S Peña', Guilherme C Cabral ${ }^{1}$, Wesley L Fotoran ${ }^{1}$, Katia R Perez ${ }^{2}$ and Beatriz S Stolf ${ }^{\star}, 1$
}

Leishmania (Leishmania) amazonensis is an important agent of cutaneous leishmaniasis in Brazil. This parasite faces cell death in some situations during transmission to the vertebrate host, and this process seems to be dependent on the activity of metacaspase (MCA), an enzyme bearing trypsin-like activity present in protozoans, plants and fungi. In fact, the association between MCA expression and cell death induced by different stimuli has been demonstrated for several Leishmania species. Regulators and natural substrates of MCA are poorly known. To fulfill this gap, we have employed phage display over recombinant L. (L.) amazonensis MCA to identify peptides that could interact with the enzyme and modulate its activity. Four peptides were selected for their capacity to specifically bind to MCA and interfere with its activity. One of these peptides, similar to ecotin-like ISP3 of $L$. (L.) major, decreases trypsin-like activity of promastigotes under heat shock, and significantly decreases parasite heat shock-induced death. These findings indicate that peptide ligands identified by phage display affect trypsin-like activity and parasite death, and that an endogenous peptidase inhibitor is a possible natural regulator of the enzyme.

Cell Death and Disease (2017) 8, e2645; doi:10.1038/cddis.2017.59; published online 2 March 2017

Leishmania (Leishmania) amazonensis is the second most frequent agent of cutaneous leishmaniasis in Brazil, ${ }^{1}$ a country with high incidence of this disease (WHO 2016).

The promastigote forms of Leishmania are transmitted to man and other mammals by the bite of an infected female sand fly. Once inside vertebrate phagocytes, promastigotes convert into the amastigote forms, responsible for disease progression. $^{2,3}$ Macrophages are the parasite's main host cells that nevertheless possess several mechanisms to restrain the infection such as by nitric oxide (NO) and reactive oxygen species (ROS) production. ${ }^{4,5}$

After transmission to the vertebrate host, promastigotes face a heat shock and an oxidative attack of the innate immune system. The exposure of promastigotes to NO, ROS, hydrogen peroxide, ${ }^{6}$ heat shock $^{7,8}$ and drugs $^{9-11}$ induces phenotypical changes characteristic of programmed cell death (PCD) such as cell shrinkage, DNA fragmentation, activation of peptidases ${ }^{12}$ and exposition of a 'PS-like' (annexin V binding) phospholipid. ${ }^{13,14}$

PCD by apoptosis is considered to be dependent on the activation of caspases, cysteine-dependent peptidases. ${ }^{15}$ Plants, fungi and protozoa do not code for caspases but express metacaspases (MCAs). ${ }^{16}$ MCAs are cysteine peptidases from clan $C D$, family $\mathrm{C} 14$, that share the histidinecysteine catalytic dyad with caspases, but differently from caspases, which are specific to aspartic acid at $\mathrm{P1}$, are specific to arginine/lysine, that is, have trypsin-like activity. ${ }^{16-19}$ MCAs have been shown to have caspase-like auto-processing, ${ }^{20}$ and for some Leishmania species, ${ }^{20,21}$ as well as yeast ${ }^{22}$ and Arabidopsis, ${ }^{23,24}$ processing of the enzyme is essential for activity.
Leishmania MCA was first described in Leishmania (L.) major $^{20}$ and in Leishmania (L.) donovani, ${ }^{25}$ and was later identified in Leishmania (L.) mexicana ${ }^{26}$ and Leishmania (L.) infantum. ${ }^{9}$ Most Leishmania species have a single MCA gene, while $L$. (L.) infantum and $L$. (L.) donovani have two genes that code for proteins with $96 \%$ identity. ${ }^{27}$ MCA has important roles not only in cell death but also in the control of amastigote intracellular proliferation ${ }^{26}$ and autophagy. ${ }^{26,28}$

The association between MCA and cell death has first demonstrated in yeast ${ }^{22}$ and Trypanosoma brucei, ${ }^{29}$ and later in Arabidopsis ${ }^{30}$ and different Leishmania species. Oxidative stress caused MCA-dependent cell death in Saccharomyces cerevisiae, and the yeast knock out strain was efficiently complemented by Leishmania (L.) major MCA. ${ }^{20}$ Accordingly, oxidative stress induced higher 'PS-like' exposure in a Leishmania (L.) major lineage that over expressed MCA catalytic region. ${ }^{21}$ Drugs such as miltefosine induced death in Leishmania (L.) infantum associated with MCA overexpression, ${ }^{9}$ and a Leishmania (L.) major MCA-deficient lineage was resistant to miltefosine and curcumin. ${ }^{28}$

Regulators and natural substrates of MCA were not frequently studied. It was recently shown by two-hybrid system that Leishmania (L.) major mitogen-activated protein kinase MPK7 and calpain interact with the C-terminal domain of MCA, probably participating on the induction of parasite death. ${ }^{28}$ No similar study was ever performed on Leishmania (L.) amazonensis MCA or other Leishmania species.

Phage display is an effective tool for searching for protein ligands, allowing the identification of natural protein interactions and of potential synthetic modulators. ${ }^{31,32}$ In this work we have employed a commercial phage display library over

${ }^{1}$ Department of Parasitology, Institute of Biomedical Sciences, University of Sao Paulo, Sao Paulo, Brazil and ${ }^{2}$ Department of Biophysics, Federal University of Sao Paulo, Sao Paulo, Brazil

${ }^{*}$ Corresponding author: Beatriz S Stolf, Department of Parasitology, Institute of Biomedical Sciences, University of Sao Paulo, 1374, Av Prof. Lineu Prestes, room 20, Sao Paulo 05508-000, Brazil. Tel: +55 113091 7271; Fax: +55 11 30917417; E-mail: bstolf@usp.br

Received 10.7.16; revised 05.12.16; accepted 18.1.17; Edited by F Madeo 
recombinant $L$. (L.) amazonensis MCA to identify peptides that could interact with the enzyme, modulating its activity and eventually affecting parasite survival. We identified peptides that specifically bind to MCA. One of them decreases trypsinlike activity in promastigotes under heat shock and reduces parasite heat shock-induced death. This peptide is similar to the $L$. (L.) major ecotin-like ISP $3,{ }^{33}$ a potent inhibitor of several serine proteases. ${ }^{34}$

Our study is the first to show that MCA can be inhibited by a peptide similar to a parasite-coded serine protease inhibitor. Besides, we show that phage display can be effectively used to identify modulators of specific Leishmania targets, suggesting that this technique can be employed to decipher poorly known processes and to search for potential parasitespecific drugs.

\section{Results}

Heat shock induces $L$. (L.) amazonensis promastigote death and increases trypsin-like activity. Leishmania faces heat shock during transmission to the vertebrate host, and this event induces death of a part of the parasite's population. ${ }^{8}$ We analyzed the effect of heat shock at $37^{\circ} \mathrm{C}$ (compared with $22^{\circ} \mathrm{C}$, the sand fly temperature) for different periods in promastigote death employing MTT assay and annexin $\mathrm{V}$ and $\mathrm{PI}$ labeling. The results shown in Figures 1 $(a-c)$ indicate that viability is significantly diminished after 2 (based on MTT, c) and $3 \mathrm{~h}$ (based on annexin V and PI, a, b) of heat shock.

MCA has already been suggested to be involved in Leishmania heat shock-induced cell death. ${ }^{21}$ We thus quantified trypsin-like activity in parasite extracts after incubation at $37^{\circ} \mathrm{C}$. Figure $1 \mathrm{C}$ demonstrates that heat shock for 1, 2, 3 and $4 \mathrm{~h}$ significantly increased activity, reinforcing the possible role for the enzyme in this process.

Production of active recombinant $L$. (L.) amazonensis MCA. Little is known about MCA substrates and regulators. Aiming to find natural or artificial ligands that could modulate enzyme activity and eventually parasite death, we employed the phage display technique on the recombinant enzyme. Bacteria were transformed with pET-28a vector containing L. (L.) amazonensis MCA gene and trypsin-like activity was assayed in extracts (Figure 2a). Activity was higher in bacteria transformed with MCA containing plasmid, as already described for plant MCA in the same system. ${ }^{24}$ This result indicated that bacteria could produce a functional (active) recombinant protein. His-tagged protein with approximately $50 \mathrm{kDa}$ was identified in bacterial extracts after induction with IPTG (Figure $2 \mathrm{~b}$ ), and was purified along with a processed form of $\sim 25 \mathrm{kDa}$ (Figure 2c), already described. $^{23}$

Identification of MCA-binding peptides able to modulate enzyme activity. Panning using the commercial Ph.D.-7 Phage Library (phages containing seven random amino acids in plll protein) was performed over the immobilized MCA protein. Three cycles were performed, and a small enrichment in the number of bound phages was observed after each cycle (Supplementary Table I). After three cycles, 50 bound phages were randomly picked and sequenced. The sequences of the corresponding peptides and their frequencies are shown in Table 1.

Phage display selection usually leads to a large number of different bound phages, and selection of the ones to be validated is usually based on their frequencies. ${ }^{35-37}$ Thirtythree different peptides were encoded by the 50 phages sequenced. Most of them were observed in only one phage, seven were present in two phages, one in four phages and two in five phages (see Table 1). We thus selected 13 peptides (named 1-13, shown in Table 1) using as criteria the identification of the peptide in more than one phage or the presence of a three amino acid repeat shared with another peptide. These peptides were synthesized and the effect of each of them on trypsin-like activity in promastigote extracts and in extracts of bacteria transformed with control vector or MCA plasmid is shown in Figure 3.

Figure 3a shows that peptides 1, 2, 10, 11 and 12 significantly increased and peptide 3 significantly decreased trypsin-like activity in promastigotes compared with control. To prove that the peptides' effects on the promastigote trypsinlike activity were due to their interaction with MCA and not with other enzymes, we analyzed the effects of peptides 1, 3, 10 and 11 on trypsin-like activity in bacteria extracts. Trypsin-like activity of bacteria expressing or not MCA in the presence of the peptides is shown in Figure $3 \mathrm{~b}$. Activity was again higher in bacteria transformed with MCA plasmid (control in grey) than with control vector (control in white), as previously shown in Figure 2a. As observed in promastigote extracts (Figure 3a), peptide 3 decreased trypsin-like activity of MCA expressing bacteria (Figure $3 b$ ). Peptides 10 and 11 showed no significant increase in activity, and peptide 1 decreased activity in bacteria, differently from promastigote data. Peptides had no effect on trypsin-like activity of bacteria transformed with control vector.

Peptides bind to recombinant MCA and to fixed and live parasites. To confirm that peptides modulated activity due to direct interaction with the enzyme we evaluated the binding of peptides 1, 3, 10 and 11 to MCA. Peptides were conjugated with Alexa 488 and incubated with either immobilized recombinant MCA or streptavidin. The results shown in Figure 4 indicate that all peptides have significant higher binding to MCA than to streptavidin, indicating that the phage selection was effective and specific.

We then tested if the peptides were able to recognize and bind to MCA in parasites. To answer this question, we incubated fixed non-permeabilized promastigotes or fixed promastigotes after heat shock $\left(1 \mathrm{~h}\right.$ at $\left.37^{\circ} \mathrm{C}\right)$ with peptides conjugated with Alexa 546 and analyzed labeling under the microscope. Representative images shown in Figure $5 a$ and the corresponding quantifications shown in Figure $5 \mathrm{~b}$ indicate that peptide 3 binds to fixed parasites previously submitted or not to heat shock, while peptides 1, 10 and 11 bind weakly in the absence of heat shock and more intensely to promastigotes submitted to incubation at $37^{\circ} \mathrm{C}$ for $1 \mathrm{~h}$. The lower binding of the other peptides compared with peptide 3 suggests that its stronger binding is not artefactual. 


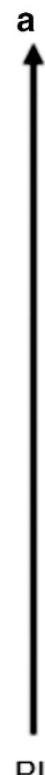
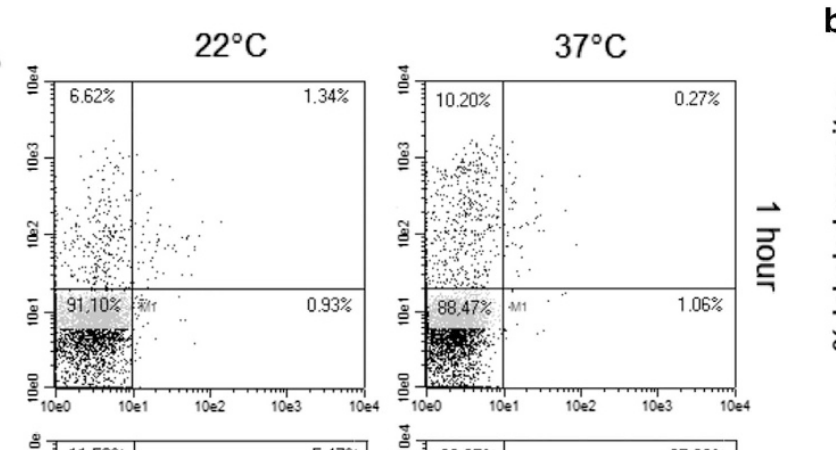

b

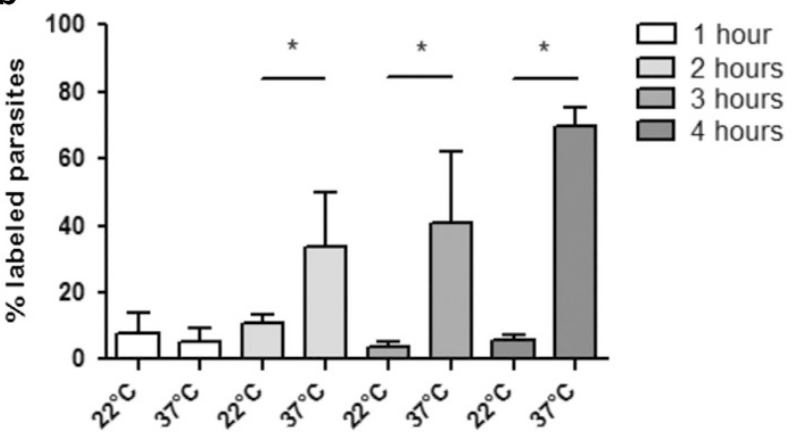

c
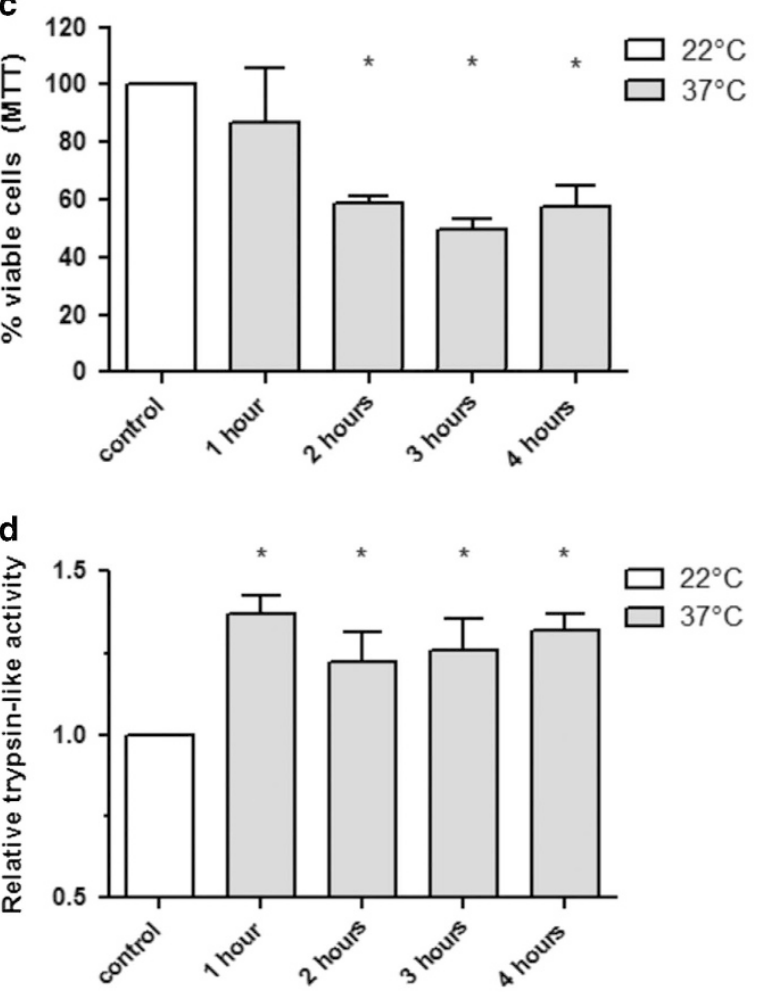

Figure 1 Heat shock induces death of $L$. (L.) amazonensis promastigotes and increases trypsin-like activity. (a) Flow cytometry plots for annexin $V$ and PI labeling of promastigotes incubated at 22 or $37^{\circ} \mathrm{C}$ for $1,2,3$ or $4 \mathrm{~h}$. (b) Percentage of parasites with annexin V or annexin V+PI labeling (named as \% labeled parasites) by flow cytometry (controls in Supplementary Figure 1). (c). MTT assay showing viability after 1, 2, 3 and $4 \mathrm{~h}$ of heat shock $\left(37^{\circ} \mathrm{C}\right)$, each of them relative to the incubation at $22{ }^{\circ} \mathrm{C}$ for the same period, considered as $100 \%$. (d). Trypsin-like activity (named as relative trypsin-like activity) using Z-Arg-Arg-AMC substrate and $2 \mu \mathrm{g}$ of extract of promastigotes incubated at $37{ }^{\circ} \mathrm{C}$, relative to the extract obtained after incubation at $22^{\circ} \mathrm{C}$ for the same period, considered as 1.0 . For all figures, data represent means and standard deviations of three independent experiments. Statistical analysis by ANOVA followed by Tukey, ${ }^{*} P<0.05$

Peptide 3, similar to ecotin, reduces trypsin-like activity and parasite death after heat shock. To test the effect of peptides in live parasites, we investigated whether the four peptides could bind (possibly enter) intact parasites by flow cytometry. Parasites showed labeling with all peptides, with low median fluorescence intensities (MFIs) (Supplementary Figure 2), suggesting that few parasites bound or internalized peptides, probably in low amounts. These results prompted us to evaluate the effect of peptides in live parasites, in an attempt to shed light on the role of the natural MCA ligand.

Considering that peptide 3 binds to immobilized MCA (Figure 4), binds to fixed and live parasites (Figure 5 and
Supplementary Figure 2), and alters enzyme activity (Figure 3), we analyzed whether it could modulate trypsinlike activity and parasite death induced by heat shock. Results shown in Figure 6 indicate that peptide 3 significantly reduces parasite trypsin-like activity (a) and parasite death (b) after heat shock. These effects are observed with at least $100 \mu \mathrm{M}$ of peptide 3 and do not increase with higher peptide concentrations (Supplementary Figure 3).

A search for possible candidates for peptide 3 indicated high identity (six of the seven amino acids of the peptide) to $L$. (L.) major ISP3, a homologous of bacterial ecotin showing $37 \%$ identity to the prokaryotic protein. This protein has not been 


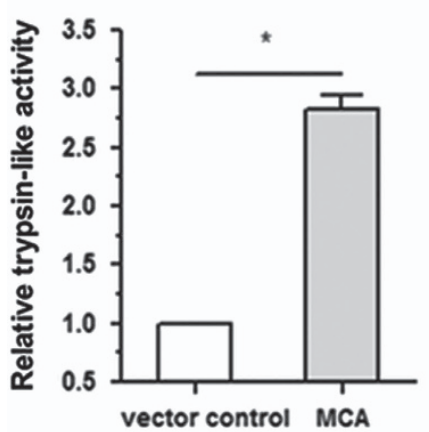

b

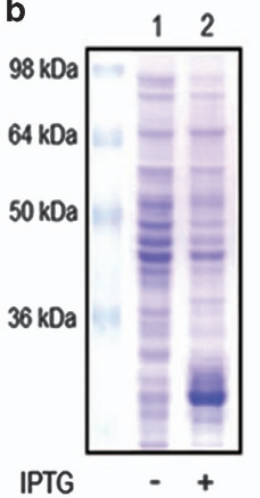

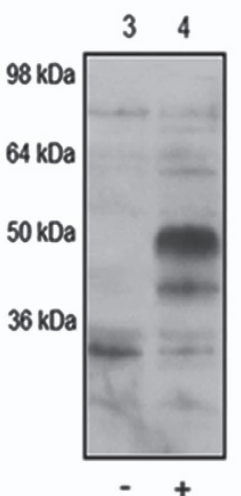

c

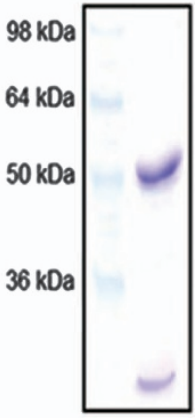

Figure 2 Recombinant MCA was effectively produced in bacterial system. (a) Trypsin-like activity (named as relative trypsin-like activity) measured in $20 \mu \mathrm{g}$ of bacterial extract transformed with control vector (pET-28a) or MCA-containing plasmid, induced with IPTG. Results of three experiments with technical triplicates. Statistical analysis by t-test, ${ }^{*} P<0.05$. (b) SDS-PAGE (lanes 1 and 2 ) and western blot (lanes 3 and 4 ) using anti-his for detection of MCA in bacterial system with (+) or without ( - ) IPTG induction. (c) SDS-PAGE showing recombinant MCA after purification

Table 1 Peptide sequences and frequencies of the 50 phages

\begin{tabular}{|c|c|c|}
\hline 1 & NHRPHLD & $1 / 50$ \\
\hline 2 & GSTPNWH & $2 / 50$ \\
\hline 3 & YAAHRSH & $5 / 50$ \\
\hline 4 & IDPQTPT & $2 / 50$ \\
\hline 5 & ADRAWAR & $2 / 50$ \\
\hline 6 & KFPAINQ & $5 / 50$ \\
\hline 7 & TNPHLNW & $1 / 50$ \\
\hline 8 & VPFPSAS & $2 / 50$ \\
\hline 9 & GVQSPHF & $4 / 50$ \\
\hline 10 & ATWVSPY & $2 / 50$ \\
\hline 11 & AFPSPTD & $1 / 50$ \\
\hline 12 & STSPESA & $1 / 50$ \\
\hline \multirow[t]{21}{*}{13} & GIHTLMG & $2 / 50$ \\
\hline & ALHGPTP & $1 / 50$ \\
\hline & APSFTKH & $1 / 50$ \\
\hline & DFHHASM & $1 / 50$ \\
\hline & FPPFQTQ & $1 / 50$ \\
\hline & GHYASGC & $1 / 50$ \\
\hline & HSAHENS & $1 / 50$ \\
\hline & ISPQTPT & $1 / 50$ \\
\hline & LIAASNN & $1 / 50$ \\
\hline & LPPSSRM & $1 / 50$ \\
\hline & NSHSMPF & $1 / 50$ \\
\hline & QFATQSH & $1 / 50$ \\
\hline & QIGYQRA & $1 / 50$ \\
\hline & QSFWFHA & $1 / 50$ \\
\hline & SVSPISH & $1 / 50$ \\
\hline & TPLTPHQ & $1 / 50$ \\
\hline & TSSHAPL & $1 / 50$ \\
\hline & VALSAPY & $1 / 50$ \\
\hline & VAPWEKL & $1 / 50$ \\
\hline & VIIVPPA & $1 / 50$ \\
\hline & YIPTAMK & $1 / 50$ \\
\hline
\end{tabular}

Peptide numbers (column 1), peptide sequences showing polar amino acids in green, hydrophobic in red, acid in blue and basic in pink (column 2), frequencies of the sequences (column 3) described nor annotated in L. (L.) amazonensis, but the corresponding gene sequence (TriTrypDB) is conserved in this species and the translated protein is $81 \%$ identical to $L$. major ISP3, suggesting that peptide 3 corresponds to endogenous L. (L.) amazonensis ISP3. Sequence alignment of $L$. (L.) amazonensis ISP3 with L. major ISP3 and Escherichia coli ecotin is shown in Figure 7a.

RT-PCR using L. (L.) amazonensis promastigoteś RNA (Figure $7 \mathrm{~b}$ ) shows that ISP3 gene is transcribed in this species, indicating that the gene is active and is not a pseudogene.

\section{Discussion}

L. (L.) amazonensis trypsin-like activity correlates with heat shock and promastigote death. We have shown for the first time that heat shock at $37^{\circ} \mathrm{C}$ induces L. (L.) amazonensis death and increases trypsin-like activity. Previous studies have shown that Leishmania MCA increases parasite death after oxidative stress. ${ }^{20,21,25}$ Besides, heat shock, oxidative stress and drugs have been shown to alter MCA processing in several Leishmania species, including L. (L.) amazonensis. ${ }^{20,21,38}$

MCA ligands alter enzyme activity. Regulators of MCA that increase enzyme activity can represent potential drugs for a specific leishmaniasis treatment. We searched for MCA modulators among ligands of the recombinant protein identified using phage display over the recombinant $L$. (L.) amazonensis enzyme. The effects of the peptides on trypsinlike activity were analyzed in Leishmania (native enzyme condition) and MCA expressing bacteria extracts, because the purified recombinant enzyme showed very low activity (data not shown). Indeed, MCAs from L. major ${ }^{20,21}$ and probably L. (L.) amazonensis, as well as yeast YCA1 (ref. 22) and Arabidopsis $\mathrm{MCA}^{23,24}$ require processing to be active, what hampers the purification of an active recombinant enzyme. In fact, the only active Leishmania recombinant enzyme described until date was the catalytic domain (equivalent to processed enzyme) of $L$. (L.) major (Gonzalez et al. $\left.^{20}\right)$. Five peptides modulated trypsin-like activity in 

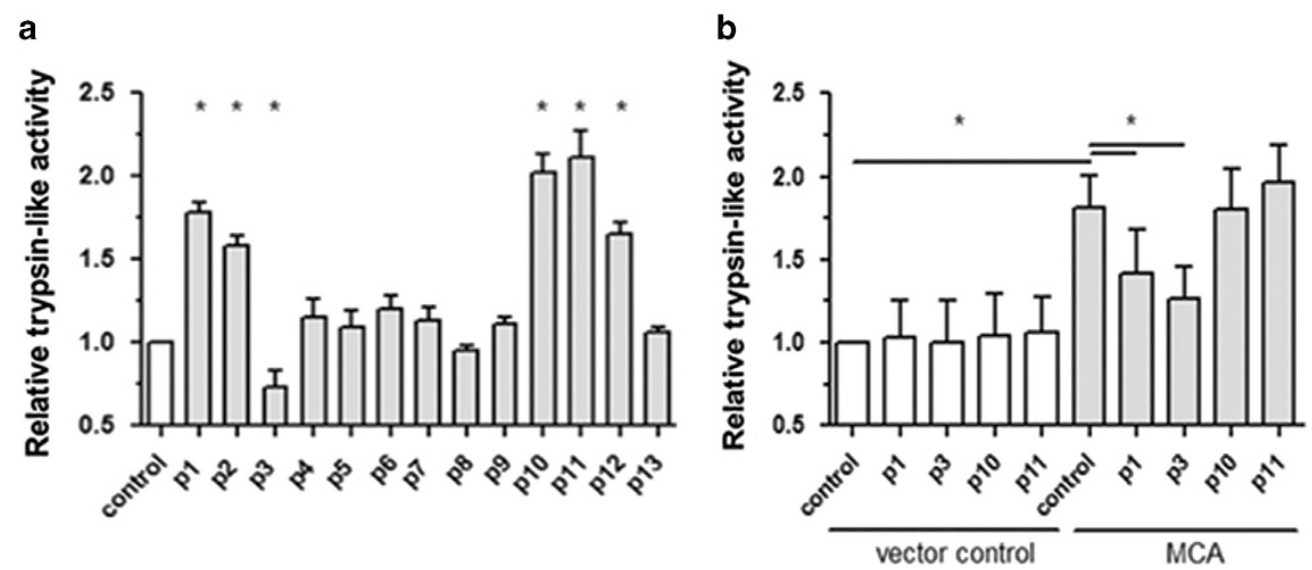

Figure 3 Peptides modulate trypsin-like activity in promastigotes and in bacteria expressing MCA. Relative trypsin-like activity of (a). Promastigote extracts pre-incubated with each of the 13 selected peptides $(100 \mu \mathrm{M})$ or with DMSO (control). (b) Bacteria expressing MCA or transformed with control vector (pET-28a), pre-incubated with p1, p3, p10 and p11 peptides $(100 \mu \mathrm{M})$ or with DMSO (control). Results of three experiments with technical triplicates, normalized by the corresponding activity in DMSO $0,5 \%$ (represented as 1.0). Statistical analysis by ANOVA followed by Tukey. ${ }^{*} P<0.05$ relative to control

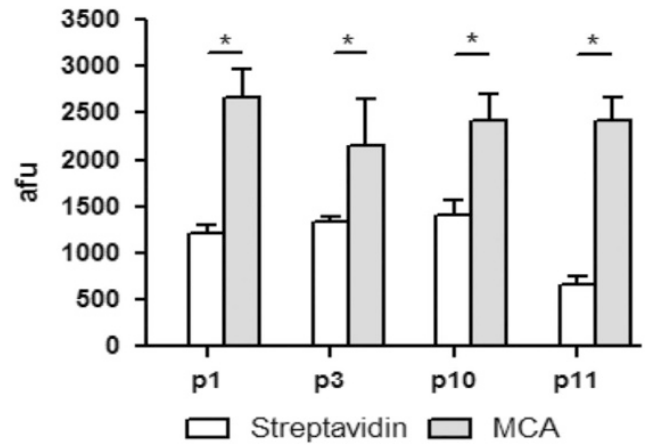

Figure 4 Peptides 1, 3, 10 and 11 bind to MCA. Binding of the four Alexa 488conjugated peptides to MCA or streptavidin. $15 \mu \mathrm{g}$ of MCA or streptavidin were immobilized in plates and incubated with $100 \mu \mathrm{M}$ of each fluorescent peptide. Results of three experiments with technical triplicates. Statistical analysis by ANOVA followed by Tukey. ${ }^{*} P<0.05$ (MCA versus streptavidin binding)

parasite extracts, but only two significantly affected trypsinlike activity in bacteria expressing MCA, both decreasing enzyme activity. Since none of the peptides affected the activity in bacteria not expressing MCA, we concluded that the effects observed were specific for MCA. Promastigotes have enzymes other than MCA with trypsin-like activity, such as cysteine proteinase $C^{38}$ and have higher activity than MCA expressing bacteria (data not shown). These facts may explain the differences between the results.

The ability of the peptides to bind to MCA was confirmed using recombinant enzyme and fixed parasites submitted or not to heat shock. Heat shock is known to promote enzyme processing, and could also alter enzyme structure and affinity to the peptides, and even open pores in the parasite membrane, facilitating peptide binding. In fact, all peptides showed visible labeling to parasites after heat shock, while peptide 3 was the only peptide with visible binding to parasites at $22^{\circ} \mathrm{C}$, suggesting a more effective interaction with the 'native' MCA inside the parasite.
Peptide 3 inhibits MCA and reduces parasite death. The four peptides could represent natural regulators of MCA or could be artificial synthetic mimotopes. To perform functional assays on the effect of the peptides in parasite death, we first checked their ability to bind/enter live cells. Although none of them had the extremely basic amino acid composition or amphipatic membranotropic composition usually found in cell penetrating peptides (CPPs), ${ }^{39,40}$ peptides 1 and 3 are predominantly basic (three out of seven amino acids) and peptide 11 predominantly nonpolar/hydrophobic (three out of seven amino acids). Peptide labeling was observed in a small proportion of the parasites, suggesting that they bound/entered cells and that functional tests in live parasites could be done.

Functional assays were performed with peptide 3, which significantly reduced trypsin-like activity and parasite death after heat shock. This data indicates that even a small inhibition of MCA by the peptide has an impact on parasite death induced by stimuli such as heat shock. We believe similar effects would be observed if parasite death was triggered by stimuli such as oxidative stress and drugs.

Although peptide 3 decreases cell death and thus could not be used as drug for parasite killing, it may shed light on natural regulators of Leishmania MCA. In fact, its similarity to parasite ecotin, more specifically ISP3, suggests that this protein regulates endogenous MCA activity and thus parasite death. First described in E. coli, ecotin is a potent inhibitor of several serine proteases. ${ }^{34} L$. (L.) major was shown to have three ecotin-like genes, named ISP 1, 2, 3 for inhibitor of serine peptidase, and ISPS 2 and 3 seem to have a role on the interaction with the host cell. ${ }^{33}$ ISP3 seems to have a very low expression in $L$. (L.) major, $^{33}$ but we were able to identify its transcript in L. (L.) amazonensis promastigotes. An ISP was recently identified in $L$. (L.) donovani, and shown to inhibit trypsin activity but not the activity of a $L$. (L.) donovani serine protease. ${ }^{41}$ Ecotin and ISPs are considered inhibitors of serine peptidase from S1A family. Genomic studies have proven that $L$. (L.) major has several serine peptidases belonging to six families but not to S1A family. ${ }^{42}$ Our findings suggest that ecotin may also inhibit cysteine proteases such 


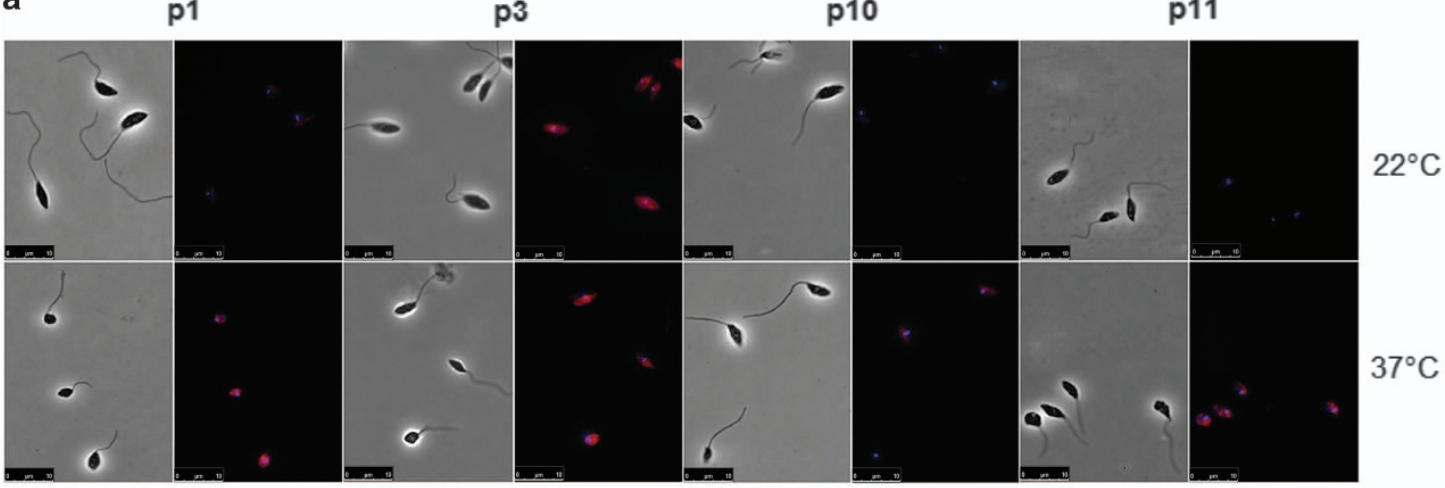

b

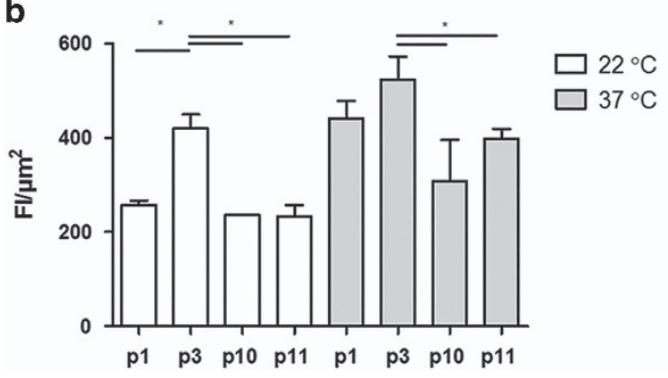

Figure 5 Peptides $1,3,10$ and 11 bind to fixed parasites previously submitted to heat shock at $37^{\circ} \mathrm{C}$ for $1 \mathrm{~h}$. (a) Promastigotes were submitted or not to heat shock, immobilized, fixed in glass slides and incubated with Alexa 546 fluorescent peptides 1, 3, 10 and 11, labeled in red. Nuclei and kinetoplasts are labeled with DAPI, in blue. Images of one experiment representative of three with similar profiles. Bars correspond to $10 \mu \mathrm{m}$. (b) Graph showing quantification of peptide binding to parasites shown in (a). Data represent mean fluorescence/ $\mu \mathrm{m} 2$ of three promastigotes, determined using Image $J$
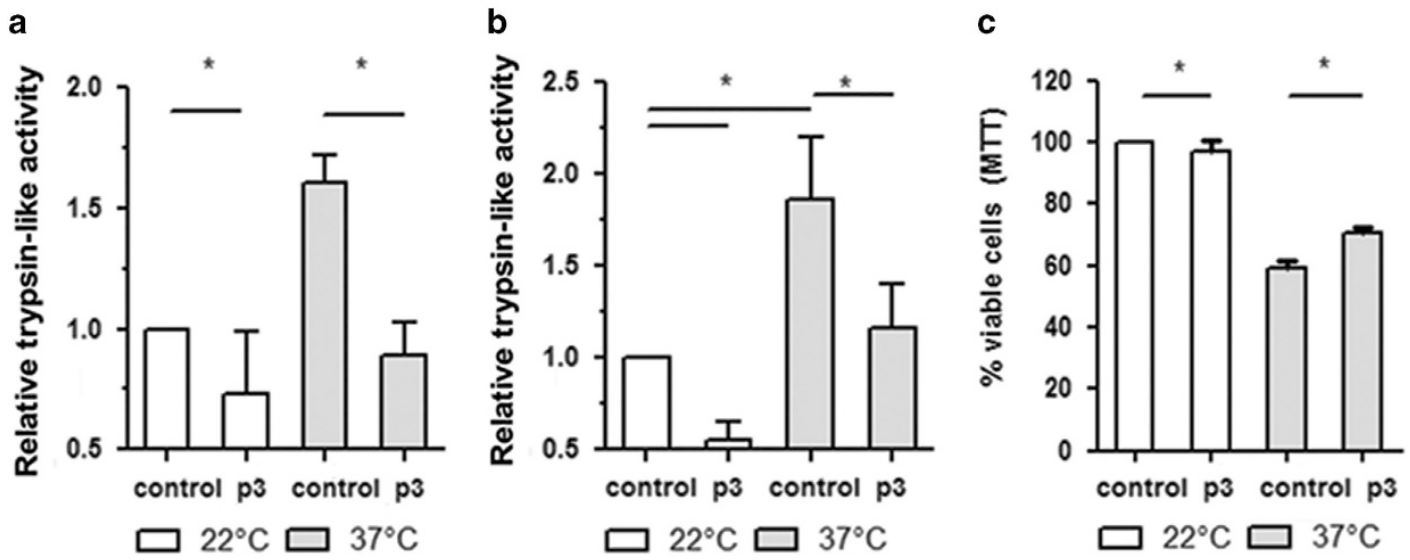

Figure 6 Incubation of parasites with peptide 3 reduces trypsin-like activity and parasite death after heat shock. (a and $\mathbf{b})$ Relative trypsin-like activity of promastigotes preincubated with peptide $3(100 \mu \mathrm{M})$ or DMSO (control), submitted $\left(37^{\circ} \mathrm{C}\right)$ or not $\left(22{ }^{\circ} \mathrm{C}\right)$ to heat shock for $1(\mathbf{a})$ and $2(\mathbf{b})$ hours, relative to control at $22{ }^{\circ} \mathrm{C}$. (c). Viability (by MTT) of promastigotes pre-incubated with peptide $3(100 \mu \mathrm{M})$ or DMSO (control) submitted $\left(37^{\circ} \mathrm{C}\right)$ or not $\left(22^{\circ} \mathrm{C}\right)$ to heat shock for $2 \mathrm{~h}$, relative to control at $22^{\circ} \mathrm{C}$. Results of three experiments with technical triplicates. ANOVA followed by Tukey, ${ }^{\star} P<0.05$

as MCA. Besides, we show that phage display is an efficient tool to search for ligands and regulators of proteins and enzymes with poorly known pathways.

\section{Conclusion}

Our data demonstrate that L. (L.) amazonensis trypsin-like activity and promastigote death are induced by heat shock. We showed that peptides that bind to recombinant MCA, selected by phage display, may affect enzyme activity. One of the peptides, similar to Leishmania ISP3, is able to reduce parasite trypsin-like activity induced by heat shock and promastigote death after the shock. We suggest for the first time that ISP3, considered a serine peptidase inhibitor, may also inhibit cysteine proteases such as MCAs.

\section{Material and Methods}

Leishmania (L.) amazonensis promastigotes. Promastigotes of Leishmania (L.) amazonensis LV79 (MPRO/BR/72/M1841) or M2269 (MHOM/BR/ 1973/M2269) strains were cultured at $24^{\circ} \mathrm{C}$ in M199 medium supplemented with 
a

E.coli

L.major

L. amazonensis

E.coli

L.major

L. amazonensis

E.coli

L.major

L. amazonensis

E.coli

L. major

L. amazonensis

E.coli

L.major

L. amazonensis

E.coli

L.major

L. amazonensis

SPSRPRLSSTAYWPQENSKTKRSPSATHKPRRSTDSAAIEETGVGTPKKNRSSSGSASNK

SPSHPRLSSTECWTPESPKTRRSPSATQKPRRSTDSVAIEETGGSASKKNRSSSGSAPNK

MKTILPAVLFAAFATTSAWAAESVQPLEKIAPYPQAEKGMKRQVIQLTQQE--- DESTLK -MPSLDYH - VPYPAAAPGQVRKVIYLPRQNPTVEQQHLR -MPSLQDYR - -VPYPAAAPGQVRKVIYLPQQNPTVEQQHLR

VELLIGQTLEV-DCNLHRLGGKLESKTLEGWGYDYYFDKVSSPVSTMMACPDGKKEKKF VQIIPGRHENCDDGRLYKLTGSVTEETLQGWGYSYYW-TLGDIYAAHRSSSDPARATTF VQIIPGRHENCEDGRLYKLTGSWEETLQGWGYSYWV-TLGDMYAAHRSSSDPEHATTF

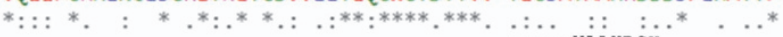
peptide 3 YAAHRSH

VTAYLGDAGMLRYNSKLPIWYTPDNVDVKYRIWKAEEKIDNAWVR - . VA--LDESPVIAYNSKLPIWNVPEGAELRYRIWTDDASLAQSIQQKPEAPALPQPHLVP VA--LDESPVIAYNSRLPIWWVEGAEVRYRIWTDDASLVQSVQQQPEAPAVPQPRLAT

VTEGQECPQELPRCGAPSEYVRQDYKASMLSVEEVHRLSNNTPPLIPSAVHESAHEAHAA VTVRQECPQR - - -GAPSEYTQAYKRPSLSVEEVHRPSSNRPHLIPSAVHESTHEAHAA

PPLHSAVLEEHGRPGMEHLEVCPKNNGSEGREQPAEEASTLKORSSSSSSNPRHHSANES PPLHSAELGEHARPAMENLEVCPQNNGHEGREQPAEKASTLKRR-SSSSSNTQNHSTNES b *: *. : : : : ***.******.*: . : : :****. : . : : : : .

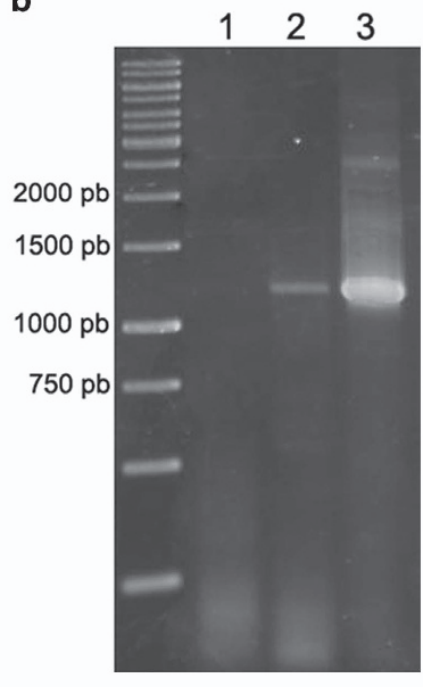

E.coli

L.major

L. amazonensis

RKAEDDVYEKTMKNFINRARSDSPRKASASSTKSGNGSKADPVDGK

SKAGDDAYEKTMKDLWNRARSDSPRKPSASSRRSGNGSKADP ...

Figure 7 ISP3 sequence and expression in L. (L.) amazonensis. (a) Alignment of protein sequences of E. coli ecotin, L. major ISP3 and L. (L.) amazonensis (deduced) ISP3, showing peptide 3 corresponding sequence. (b) Expression of ISP3 in L. (L.) amazonensis promastigotes by RT-PCR. Lane 1: PCR negative control (RNA), lane 2: PCR of cDNA, lane 3: PCR of genomic DNA

$10 \%$ fetal calf serum (FCS). Parasites were sub-cultured every 7 days at inoculums of $2 \times 10^{6} / \mathrm{ml}$.

Heat shock. Promastigotes at day 3 (log phase) were resuspeded at the density of $5 \times 10^{7}$ parasites $/ \mathrm{ml}$ in $116 \mathrm{mM} \mathrm{NaCl}, 10 \mathrm{mM} \mathrm{CaCl} 2,5,4 \mathrm{mM} \mathrm{KCl}, 0,8 \mathrm{mM}$ $\mathrm{MgSO}_{4}, 5,5 \mathrm{mM}$ D-glicose, $50 \mathrm{mM}$ MOPS (3-N-Morpholino propanesulfonic acid pH $7,4)$ and incubated at 22 or $37^{\circ} \mathrm{C}$ in media only or with peptides or DMSO during different periods.

MTT assay. $100 \mu$ l of parasites incubated at 22 or $37^{\circ} \mathrm{C}$ were transferred to 96 well plates. $20 \mu$ of MTT (MTT (3-[4,5-dimethylthiazol-2-yl]-2,5-diphenyltetrazolium bromide $5 \mathrm{mg} / \mathrm{ml}$ in PBS) were added and the plate was incubated at $22{ }^{\circ} \mathrm{C}$ for $50 \mathrm{~min} .100 \mu \mathrm{l}$ of SDS $10 \%$ were added and absorbance at $595 \mathrm{~nm}$ (reference at $655 \mathrm{~nm}$ ) was measured in a BioTek ELx800 equipment (Biotek., Winooski, VT, USA).

Annexin V and PI labeling by flow cytometry. Promastigotes at log phase (day 3) were centrifuged at $4000 \times g$ for 5 min and washed three times in Hepes buffer (100 mM Hepes, $150 \mathrm{mM} \mathrm{NaCl}, 5 \mathrm{mM} \mathrm{KCl}, 3 \mathrm{mM} \mathrm{CaCl} 2,1 \mathrm{mM} \mathrm{MgCl}_{2}$, $\mathrm{pH} 7,2)$. Parasites were resuspended at $5 \times 10^{6} \mathrm{cells} / \mathrm{ml}$ in the same buffer and $200 \mu$ l were incubated with annexin V Alexa Fluor $4881: 200$ for $20 \mathrm{~min}$ on ice, then washed three times and incubated with $10 \mu \mathrm{g} / \mathrm{ml}$ propidium iodide (IP) for $20 \mathrm{~min}$. As positive control we treated parasites with $100 \mu \mathrm{M}$ digitonin in annexin $\mathrm{V}$ reaction. 30.000 events were captured for each sample in Guava easycyte (Millipore, Bedford, MA, USA).

Trypsin-like activity of soluble extracts of promastigotes and bacteria. $10^{8}$ promastigotes were lysed in $200 \mu$ l of lysis buffer containing $20 \mathrm{mM}$ PIPES, $100 \mathrm{mM} \mathrm{NaCl}, 1 \mathrm{mM}$ EDTA, 0,1\% CHAPS, 10\% sucrose, 0,1\% Triton X-100 pH 7,2, with $1 \mathrm{mM}$ PMSF, $2 \mu \mathrm{M}$ Pepstatin A and $50 \mu \mathrm{M}$ digitonin on ice for $30 \mathrm{~min}$. The lysate was centrifuged at $16000 \times \mathrm{g}$ at $4^{\circ} \mathrm{C}$ for $5 \mathrm{~min}$, soluble fraction was collected and proteins were measured using Bradford assay (BioRad, SP, Brazil).
$10 \mathrm{ml}$ of $E$. coli BL21 (DE3) expressing MCA or containing pET28a plasmid were centrifuged at $16000 \times g$ at $4{ }^{\circ} \mathrm{C}$ for $20 \mathrm{~min}$, resuspended in $250 \mu$ lysis buffer containing $0,4 \mathrm{mg} / \mathrm{ml}$ lysozyme, and kept on ice for $1 \mathrm{~h}$ with vortexing every $10 \mathrm{~min}$. The lysate was then centrifuged as described above.

For both promastigote and bacteria lysates, activity was assayed in 96-well Costar 3603 plates (Costar-Sigma, SP, Brazil) in $100 \mu$ l of buffer containing $50 \mathrm{mM}$ Tris- $\mathrm{HCl}$, $15 \mathrm{mM} \mathrm{NaCl}, 5 \mathrm{mM}$ DTT, $10 \mathrm{mM}$ de $\mathrm{CaCl}, \mathrm{pH}$ 8.0. Extracts were added in the presence or not of peptides or DMSO and incubated for $2 \mathrm{~h}$ at $22^{\circ} \mathrm{C}$. Z-Arg-Arg-AMC substrate was added for $10 \mu \mathrm{M}$ and capture was performed at $30.5^{\circ} \mathrm{C}$ in a POLARstarOmega (BMG, Ortenberg, Germany) fluorimeter excitation at $380 \mathrm{~nm}$ and emission at $460 \mathrm{~nm}$.

SDS-PAGE and western blot. Gels and membranes were prepared as described before, ${ }^{43}$ using $10 \mu \mathrm{g}$ of proteins and $1 \mu \mathrm{g}$ of recombinant MCA.

Production of recombinant metacaspase. Metacaspase (MetaLa) gene was amplified from $L$. (L.) amazonensis using primers based on $L$. (L.). mexicana metacaspase sequence (MetaLaF 5'ATGGCAGACTTTCTTGATATTTTGGGG3' and MetaLaR 5'TTACCCAGGCGGAGCCG3'). Amplification product was cloned into the pCR4 TOPO sequencing vector (LifeTechnologies, Thermo Fisher, SP, Brazil) and then into the pET28a expression vector, generating pET-28aMeta construct. Escherichia coli BL21 (DE3) was transformed with pET-28a and pET-28aMeta, and induced with 0.1 or $1 \mathrm{mM} \mathrm{IPTG}$ at $37^{\circ} \mathrm{C}$ for $4 \mathrm{~h}$. Bacteria were centrifuged and lysed by sonication (Unique Ultrasonic DES500, SP, Brazil) in $57 \mathrm{mM} \mathrm{NaH}_{2} \mathrm{PO}_{4}$, $1.2 \mathrm{M} \mathrm{NaCl} \mathrm{pH} \mathrm{7,0} \mathrm{with} 0.4 \mathrm{mg} / \mathrm{ml}$ lysozyme and $1 \mathrm{mM}$ PMSF. Lysates were centrifuged, filtered in $0.45 \mu \mathrm{M}$ and transferred to Niquel Ni-NTA column (Qiagen). Column was washed with $57 \mathrm{mM} \mathrm{NaH}_{2} \mathrm{PO}_{4} \mathrm{pH}$ 6.0, $128 \mathrm{mM} \mathrm{NaCl}, 20 \mathrm{mM}$ imidazol and $10 \%$ glycerin and recombinant protein was eluted with $500 \mathrm{mM}$ imidazol in wash buffer, dialyzed against $57 \mathrm{mM} \mathrm{NaH}_{2} \mathrm{PO}_{4}, 1.2 \mathrm{M} \mathrm{NaCl} \mathrm{pH} 7.0$ and quantified using Bradford assay (Bio Rad, SP, Brazil).

Phage display selection. $15 \mu \mathrm{g}$ of $\mathrm{MCA} 100 \mu \mathrm{g} / \mathrm{ml}$ in $0.1 \mathrm{M} \mathrm{NaHCO}_{3} \mathrm{pH} 8,6$ were incubated in 96 -well plates (Costar EIA/RIA High binding) at $4{ }^{\circ} \mathrm{C}$ o/n. Wells 
were blocked with $150 \mu \mathrm{l}$ of $5 \mathrm{mg} / \mathrm{ml} \mathrm{BSA}$ in $0.1 \mathrm{M} \mathrm{NaHCO}_{3} \mathrm{pH} 8,6$ for $1 \mathrm{~h}$ at $4{ }^{\circ} \mathrm{C}$,

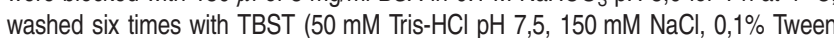
20) and incubated with $2 \times 10^{11}$ phages from Ph.D.- 7 Phage Display Peptide Library Kit (New England Biolabs, Ipswich, MA, USA) in $100 \mu \mathrm{l}$ of TBST for $1 \mathrm{~h}$ at room temperature. Unbound phages were removed by 10 washing steps in TBST and bound phages were recovered by incubation with $200 \mu$ l of exponentially growing $\left(\mathrm{OD}_{600}=0,5\right) \mathrm{E}$. coli (ER2738) for $5 \mathrm{~min}$ at room temperature. Tittering and amplification were performed as recommended.

Binding of peptides to metacaspase. $15 \mu \mathrm{g}$ of MCA or $15 \mathrm{ug}$ streptavidin in $150 \mu \mathrm{l}$ of $0.1 \mathrm{M} \mathrm{NaHCO}_{3} \mathrm{pH} 8,6$ were incubated in 96-well plates (Costar3603) at $4{ }^{\circ} \mathrm{Co} / \mathrm{n}$. Wells were blocked with $150 \mu \mathrm{l}$ of $1 \% \mathrm{BSA}$ in $0.1 \mathrm{M}$ $\mathrm{NaHCO}_{3} \mathrm{pH} 8,6$ for $1 \mathrm{~h}$ at $4{ }^{\circ} \mathrm{C}$, washed six times with PBS and incubated with $100 \mu \mathrm{M}$ of Alexa Fluor 488 conjugated peptide (labeled with Protein Labeling KitThermofisher, SP, Brazil) for $1 \mathrm{~h}$ at $4{ }^{\circ} \mathrm{C}$. Binding was estimated after analysis in POLARstar Omega at $488 \mathrm{~nm}$ for excitation and $520 \mathrm{~nm}$ for emission.

Labeling of parasites with fluorescent peptides. For the binding analysis, promastigotes were washed in PBS, fixed in 4\% paraformaldehyde for $30 \mathrm{~min}$, resuspended in PBS and applied in glass slides. After drying, slides were blocked with $1 \%$ BSA in PBS for $1 \mathrm{~h}$, washed in PBS and incubated with $100 \mu \mathrm{M}$ Alexa Fluor 546 peptide in PBS 1\% BSA o/n. Slides were then washed in PBS, incubated with $1 \mu \mathrm{M}$ DAPI in PBS $1 \%$ BSA for $1 \mathrm{~h}$, dried and mounted in ProLong (Molecular Probes,Thermo Fisher, SP, Brazil). Images were captured in ZEISS Axio Imager M2 Imaging System (Oberkochen, Germany) and quantification was performed using ImageJ (Bethesda, MD, USA), and expressed as of fluorescence intensity/ $\mu \mathrm{m} 2$ (mean values of three parasites normalized by parasite area).

For the evaluation of peptide entry in intact promastigotes we used flow cytometry and the same Alexa Fluor 546 peptides. Promastigotes were incubated for $2 \mathrm{~h}$ at $22{ }^{\circ} \mathrm{C}$ with $100 \mu \mathrm{M}$ Alexa Fluor 546 peptide in HEPES buffer $10 \mathrm{mM}$, washed in PBS and analyzed in Guava easycyte cytometer (Millipore).

RT-PCR. RNA was isolated from $5 \times 10^{7}$ promastigotes using Trizol reagent (Life Technologies). cDNA was prepared from $2 \mu \mathrm{g}$ of RNA using random primers, oligodT and Superscript II Reverse Transcriptase (Life Technologies) in $20 \mu \mathrm{l}$. PCR was performed with $2 \mu \mathrm{l}$ cDNA reaction $1: 10$, the corresponding RNA mass or $70 \mathrm{ng}$ of genomic DNA, using $0.7 \mathrm{U}$ Taq polymerase (Life Technologies) and the following cycle conditions: $94^{\circ} \mathrm{C}$ for 4 min, 35 cycles of $94^{\circ} \mathrm{C} 30 \mathrm{~s}, 60^{\circ} \mathrm{C} 45 \mathrm{~s}, 72^{\circ}$ C $2 \mathrm{~min}$ and $72{ }^{\circ} \mathrm{C}$ for $10 \mathrm{~min}$.

Statistical analysis. GraphPad software (San Diego, CA, USA) was used to perform all analysis. We employed one way ANOVA followed by Tukey's multiple comparison test (for three or more samples), or $t$-test (for comparison of two conditions).

\section{Conflict of Interest}

The authors declare no conflict of interest.

Acknowledgements. We thank Marcello Barcinski for important discussions in the beginning of this project and Silvia Uliana and Silvia Boscardin for suggestions during this work and revision of the manuscript. We also thank Iolanda Cuccovia for help with dissociation experiments, Enrique Boccardo for K12 bacteria, Claudio Marinho for fluorescent microscope, Gerhard Wunderlich for cytometer and Mariana Galuppo and Eloiza de Rezende for parasite maintenance in the laboratory. This work was supported by FAPESP (grant number 2011/12634-9) to BSS.

1. Gontijo B, de Carvalho Mde L. American cutaneous leishmaniasis. Rev Soc Bras Med Trop 2003; 36: 71-80

2. Alexander J, Satoskar AR, Russell DG. Leishmania species: models of intracellular parasitism. J Cell Sci 1999; 112: 2993-3002.

3. Bates PA. Transmission of Leishmania metacyclic promastigotes by phlebotomine sand flies. Int J Parasitol 2007; 37: 1097-1106.

4. Mills CD, Kincaid K, Alt JM, Heilman MJ, Hill AM. M-1/M-2 macrophages and the Th1/Th2 paradigm. J Immunol 2000; 164: 6166-6173.

5. Mukbel RM, Patten C Jr., Gibson K, Ghosh M, Petersen C, Jones DE. Macrophage killing of Leishmania amazonensis amastigotes requires both nitric oxide and superoxide. Am J Trop Med Hyg 2007; 76: 669-675.
6. Das M, Mukherjee SB, Shaha C. Hydrogen peroxide induces apoptosis-like death in Leishmania donovani promastigotes. J Cell Sci 2001; 114: 2461-2469.

7. Alzate JF, Alvarez-Barrientos A, Gonzalez VM, Jimenez-Ruiz A. Heat-induced programmed cell death in Leishmania infantum is reverted by $\mathrm{Bcl}-\mathrm{X}(\mathrm{L})$ expression. Apoptosis 2006; 11: 161-171.

8. Moreira ME, Del Portillo HA, Milder RV, Balanco JM, Barcinski MA. Heat shock induction of apoptosis in promastigotes of the unicellular organism Leishmania (Leishmania) amazonensis. J Cell Physiol 1996; 167: 305-313.

9. Khademvatan S, Neisi N, Maraghi S, Saki J. Diagnosis and identification of Leishmania spp. from Giemsa-stained slides, by real-time PCR and melting curve analysis in south-west of Iran. Ann Trop Med Parasitol 2011; 105: 559-565.

10. Paris C, Loiseau PM, Bories C, Breard J. Miltefosine induces apoptosis-like death in Leishmania donovani promastigotes. Antimicrob Agents Chemother 2004; 48: 852-859.

11. Verma NK, Dey CS. Possible mechanism of miltefosine-mediated death of Leishmania donovani. Antimicrob Agents Chemother 2004; 48: 3010-3015.

12. Proto WR, Coombs GH, Mottram JC. Cell death in parasitic protozoa: regulated or incidental? Nat Rev Microbiol 2013; 11: 58-66.

13. van Zandbergen G, Bollinger A, Wenzel A, Kamhawi S, Voll R, Klinger M et al. Leishmania disease development depends on the presence of apoptotic promastigotes in the virulent inoculum. Proc Natl Acad Sci USA 2006; 103: 13837-13842.

14. Wanderley JL, Moreira ME, Benjamin A, Bonomo AC, Barcinski MA. Mimicry of apoptotic cells by exposing phosphatidylserine participates in the establishment of amastigotes of Leishmania (L) amazonensis in mammalian hosts. J Immunol 2006; 176: 1834-1839.

15. Leist $M$, Jaattela M. Four deaths and a funeral: from caspases to alternative mechanisms. Nat Rev Mol Cell Biol 2001; 2: 589-598.

16. Lam E, Zhang Y. Regulating the reapers: activating metacaspases for programmed cell death. Trends Plant Sci 2012; 17: 487-494.

17. Uren AG, O'Rourke K, Aravind LA, Pisabarro MT, Seshagiri S, Koonin EV et al. Identification of paracaspases and metacaspases: two ancient families of caspase-like proteins, one of which plays a key role in MALT Iymphoma. Mol Cell 2000; 6: 961-967.

18. Vercammen D, Declercq W, Vandenabeele P, Van Breusegem F. Are metacaspases caspases? J Cell Biol 2007; 179: 375-380.

19. Meslin B, Zalila H, Fasel N, Picot S, Bienvenu AL. Are protozoan metacaspases potential parasite killers? Parasit Vectors 2011; 4: 26.

20. Gonzalez IJ, Desponds C, Schaff C, Mottram JC, Fasel N. Leishmania major metacaspase can replace yeast metacaspase in programmed cell death and has arginine-specific cysteine peptidase activity. Int J Parasitol 2007; 37: 161-172.

21. Zalila H, Gonzalez IJ, El-Fadili AK, Delgado MB, Desponds C, Schaff C et al. Processing of metacaspase into a cytoplasmic catalytic domain mediating cell death in Leishmania major. Mol Microbiol 2011; 79: 222-239.

22. Madeo F, Herker E, Maldener C, Wissing S, Lachelt S, Herlan M et al. A caspase-related protease regulates apoptosis in yeast. Mol Cell 2002; 9: 911-917.

23. Vercammen D, van de Cotte B, De Jaeger G, Eeckhout D, Casteels P, Vandepoele K et al. Type II metacaspases Atmc4 and Atmc9 of Arabidopsis thaliana cleave substrates after arginine and lysine. J Biol Chem 2004; 279: 45329-45336.

24. Watanabe N, Lam E. Two Arabidopsis metacaspases AtMCP1b and AtMCP2b are arginine/ lysine-specific cysteine proteases and activate apoptosis-like cell death in yeast. J Biol Chem 2005; 280: 14691-14699.

25. Lee N, Gannavaram S, Selvapandiyan A, Debrabant A. Characterization of metacaspases with trypsin-like activity and their putative role in programmed cell death in the protozoan parasite Leishmania. Eukaryot Cell 2007; 6: 1745-1757.

26. Castanys-Munoz E, Brown E, Coombs GH, Mottram JC. Leishmania mexicana metacaspase is a negative regulator of amastigote proliferation in mammalian cells. Cell Death Dis 2012; 3: e385.

27. Gannavaram S, Debrabant A. Programmed cell death in Leishmania: biochemical evidence and role in parasite infectivity. Front Cell Infect Microbiol 2012; 2: 95.

28. Casanova M, Gonzalez IJ, Sprissler C, Zalila H, Dacher M, Basmaciyan L et al. Implication of different domains of the Leishmania major metacaspase in cell death and autophagy. Cell Death Dis 2015; 6: e1933.

29. Szallies A, Kubata BK, Duszenko M. A metacaspase of Trypanosoma brucei causes loss of respiration competence and clonal death in the yeast Saccharomyces cerevisiae. FEBS Lett 2002; 517: 144-150.

30. He R, Drury GE, Rotari VI, Gordon A, Willer M, Farzaneh T et al. Metacaspase-8 modulates programmed cell death induced by ultraviolet light and $\mathrm{H} 2 \mathrm{O} 2$ in Arabidopsis. J Biol Chem 2008; 283: 774-783.

31. Willats WG. Phage display: practicalities and prospects. Plant Mol Biol 2002; 50: 837-854.

32. Kurzepa A, Dabrowska K, Switala-Jelen K, Gorski A. Molecular modification of T4 bacteriophage proteins and its potential application-review. Folia Microbiol (Praha) 2009; 54: 5-15.

33. Eschenlauer SC, Faria MS, Morrison LS, Bland N, Ribeiro-Gomes FL, DosReis GA et al. Influence of parasite encoded inhibitors of serine peptidases in early infection of macrophages with Leishmania major. Cell Microbiol 2009; 11: 106-120.

34. McGrath ME, Gillmor SA, Fletterick RJ. Ecotin: lessons on survival in a protease-filled world. Protein Sci 1995; 4: 141-148.

35. Bover LC, Cardo-Vila M, Kuniyasu A, Sun J, Rangel R, Takeya M et al. A previously unrecognized protein-protein interaction between TWEAK and CD163: potential biological implications. J Immunol 2007; 178: 8183-8194. 
36. Karjalainen K, Jaalouk DE, Bueso-Ramos CE, Zurita AJ, Kuniyasu A, Eckhardt BL et al. Targeting neuropilin-1 in human leukemia and lymphoma. Blood 2011; 117: 920-927.

37. Sainath Rao S, Mohan KV, Atreya CD. A peptide derived from phage display library exhibits antibacterial activity against $E$. coli and Pseudomonas aeruginosa. PloS One 2013; 8 e56081.

38. El-Fadili AK, Zangger H, Desponds C, Gonzalez IJ, Zalila H, Schaff C et al. Cathepsin B-like and cell death in the unicellular human pathogen Leishmania. Cell Death Dis 2010; 1: e71.

39. Jiao CY, Delaroche D, Burlina F, Alves ID, Chassaing G, Sagan S. Translocation and endocytosis for cell-penetrating peptide internalization. I Biol Chem 2009; 284 33957-33965.

40. Falanga A, Galdiero M, Galdiero S. Membranotropic cell penetrating peptides: the outstanding journey. Int J Mol Sci 2015; 16: 25323-25337.

41. Alam MN, Das P, De T, Chakraborti T. Identification and characterization of a Leishmania donovani serine protease inhibitor: possible role in regulation of host serine proteases. Life Sci 2016; 144: 218-225.

42. Ivens AC, Peacock CS, Worthey EA, Murphy L, Aggarwal G, Berriman M et al. The genome of the kinetoplastid parasite, Leishmania major. Science 2005; 309: 436-442.

43. Teixeira PC, Velasquez LG, Lepique AP, de Rezende E, Bonatto JM, Barcinski MA et al. Regulation of Leishmania (L.) amazonensis protein expression by host $\mathrm{T}$ cell dependent responses: differential expression of oligopeptidase $B$, tryparedoxin peroxidase and HSP70 isoforms in amastigotes isolated from BALB/c and BALB/c nude mice. PLOS Negl Trop Dis 2015; 9: e0003411.

Cell Death and Disease is an open-access journal published by Nature Publishing Group. This work is licensed under a Creative Commons Attribution 4.0 International License. The images or other third party material in this article are included in the article's Creative Commons license, unless indicated otherwise in the credit line; if the material is not included under the Creative Commons license, users will need to obtain permission from the license holder to reproduce the material. To view a copy of this license, visit http://creativecommons.org/licenses/by/4.0/

(C) The Author(s) 2017

Supplementary Information accompanies this paper on Cell Death and Disease website (http://www.nature.com/cddis) 